\title{
LOCUS OF CONTROL ANALYSED WITH REGARDS TO NON-TRADITIONAL TERTIARY STUDENTS OF EDUCATION
}

\author{
JOSEF MALACH, \\ DANA VICHERKOVÁ, \\ TOMÁŠ BAROT
}

\begin{abstract}
Locus of control, as a psychological characteristic, influences the experience and behaviour of individuals in all life situations, including the moment when an adult enters university and becomes a non-traditional student. Research on the locus of control of students at a faculty preparing experts for educational professions (teachers of all levels, social and special pedagogues, and andragogues) was initiated due to the increasing failure rate of non-traditional students within university efforts to achieve quality in all teaching activities and the need to verify the assumption that most applicants with an internal locus of control (ILC) choose an educational profession requiring management of other people's learning. The Zemanová Dolejš Locus of Control Scale revealed a dominant ILC or external (ELC) localisation of the locus of control in all 411 tertiary students, 152 of whom were non-traditional students. Considering their distribution into ILC and ELC, statistically significant relationships were identified in locus of control according to the form of study. For non-traditional students, no statistically significant relationships were found for age or type or years of study for either ILC or ELC.
\end{abstract}

\section{Keywords}

non-traditional tertiary students, internal locus of control, external locus of control, education-oriented profession 


\section{Introduction}

Locus of control (LOC), as a psychological characteristic, influences the experience and behaviour of individuals in all life situations, including the moment when an adult enters university and becomes a non-traditional student. In the more than 60 years since the introduction of this construct into psychological, managerial, educational, and sociological theory and practice by Rotter (1966), the tools for its assessment have changed. Several empirical studies have been conducted to validate the tools and determine whether, or to what extent, an individual's LOC is related to their professional, managerial, or academic success; experience of success or failure; life satisfaction; or health. Dividing individuals into groups with an internal (ILC) or external (ELC) LOC retains many proponents because of its twodimensionality, which is efficient for research and practically more accessible to use than multidimensional approaches are.

Three stimuli initiated the intention to examine the LOC of university students in part-time studies at a faculty preparing experts for educational professions (teachers of all levels, social and special pedagogues, and andragogues), namely: an increasing failure rate of students in part-time forms of study; the university's efforts to achieve high quality in all performed activities, especially pedagogical ones; and inspiration from business theory, which considers future or current entrepreneurs' LOC as one of the essential predictors of business success.

Research on the possible connections between LOC and the course and results of education in different age cohorts does not have a very long history. In recent years, however, these areas have increasingly become the subject of research interest mainly due to the proven relationship between students having an ILC and their achieving academic success and at the same time one between students having an ELC and their having difficulties throughout their studies. So far, little attention has been paid to ways to shape the perception of LOC, which cannot be considered a permanent trait but rather a result which is changeable by long-term education (in children) and targeted training and therapies and methods of teaching and communication between teachers and students (in students).

Diagnosis of the non-traditional tertiary students' LOC has not yet been a subject of research interest, although tertiary students have been researched in this respect. Our analysis of the LOC of non-traditional students in comparison to traditional students can bring hitherto unknown results usable for educational practice in tertiary institutions and thus contribute to the promising refinement of the characteristics of non-traditional university students (Brücknerová \& Rabušicová, 2019). Research into the perception of LOC has gradually expanded from managerial and business professions 
to other professions, including teaching. Identification of this trait in students preparing for various educational professions can be used in planning and designing teaching in terms of curriculum and strategy as well as in counselling and universities' therapeutic activity.

The aim of this study is to summarise current knowledge about the impact of LOC on university students (mainly non-traditional ones) in educationfocused fields - their studies and the active exercise of their professionand to empirically analyse the differences in predominant LOC (i.e. ILC or ELC) between traditional and non-traditional students and identify relationships between LOC and selected biological (gender and age) and study (form, year, type, and phase of study) variables in a sample of non-traditional students.

\section{Theoretical concept of LOC}

LOC is a psychological concept referring to how strongly people believe they have control over the situations and experiences that affect their lives. In education, LOC typically refers to how students perceive the causes of their academic success or failure (Glossary of Educational Reform, 2013). According to the American Psychological Association (n.d.), LOC is a construct used to categorise people's primary motivational orientations and perceptions of how much control they have over their lives. Rotter (1966) began to use the term in the late 1960s and also designed a tool for its assessment. From this point of view, he described two categories of individuals. Individuals with an ELC tend to behave in response to external circumstances and perceive their life outcomes as arising from factors out of their control. Individuals with an ILC tend to behave in response to internal states and intentions and perceive their life outcomes as arising from the exercise of their agency and abilities.

Výrost's (2002) research was based primarily on the LOC concept analysis formulated by Skinner. Výrost (2002) stated that the concept was developed within the theoretical foundations of social learning theory (A. Bandura), with internality or externality representing generalised expectations of the connection between an individual's behaviour and the results. Later, the theory of attribution (F. Heider) incorporated LOC into its framework, with the attribution of responsibility for the course of an event being the key to distinguishing internality and externality. Many authors have recommended replacing the term LOC with "locus of causality." Výrost (2002) considered the creation of other terms leading to "a competition between definitions of the same term" to be a state of confusion at the theoretical, empirical, and application levels. 
Gradually, certain characteristics and ways of acting and experiencing have been attributed to individuals with each LOC type as a result of empirical evidence and research data. Consequently, lists of their strengths and weaknesses have been created. Zemanová and Dolejš (2020), the authors of a Czech LOC assessment tool, developed general characteristics of individuals with each form of LOC. An individual with a higher degree of ILC is, for example, interested in education, is more productive in their work activities, is more active and engages in joint activities, uses adaptive coping strategies more frequently, is more mentally resilient, and has a lower risk of burnout. An individual with a higher degree of ELC has, for instance, less interest in learning and improving their skills, gives up faster in achieving their goals, uses passive and ineffective coping strategies more frequently, is not very creative, evaluates themselves negatively, has a lower frustration tolerance, and tends to attribute their losses and failures to external forces.

Based on Rotter's (1966) assumption that a general LOC assessment tool could be developed into a tool for specific behavioural areas, Trice (1985) introduced the concept of academic LOC and validated an appropriate assessment tool, which has predictive validity concerning academic performance.

The following characteristics are given for both groups of students according to their LOC:

Students with an "internal locus of control" generally believe that their success or failure is a result of the effort and hard work they invest in their education. Students with an "external locus of control" generally believe that their successes or failures result from external factors beyond their control, such as luck, fate, circumstance, injustice, bias, or teachers who are unfair, prejudiced, or unskilled. For example, students with an internal locus of control might blame poor grades on their failure to study, whereas students with an external locus of control may blame an unfair teacher or test for their poor performance. Whether a student has an internal or external locus of control is thought to have a powerful effect on academic motivation, persistence, and achievement in school. In education, "internals" are considered more likely to work hard in order to learn, progress, and succeed, while "externals" are more likely to believe that working hard is "pointless" because someone or something else is treating them unfairly or holding them back. Students with an external locus of control may also believe that their accomplishments will not be acknowledged, or their effort will not result in success. In special education, the locus-ofcontrol concept is especially salient. Many educators believe that students with learning disabilities are more likely to develop an external locus of control, at least in part due to negative experiences they may have had in school. (Glossary of Educational Reform, 2013).

\section{LOC assessment}

A brief introduction of selected tools for LOC assessment was guided by an effort to point out certain problems associated with comparing the results of LOC research and its connection to learning performance, motivation, engagement, and other internal factors that arise from using different 
assessment tools to identify an individual's LOC. The overview of tools was built using the "general to special" method, with tools applicable to the whole population being listed first, followed by tools focused on the youth population, then the school population, then the university student population, and finally the teaching profession.

Rotter's (1966) Internal-External Locus of Control Scale is of general use and originally consisted of 29 items, each of which contained two statements. The subject was supposed to select one statement. A high score suggested an ELC and a low score indicated an ILC. Many changes and adjustments have taken place since its introduction.

Suárez-Álvarez et al. (2016) verified a new version of the bi-dimensional general measure, containing a total of 23 items using Likert scales, with a value of 1 indicating complete disagreement with the statement and a value of 5 expressing complete agreement. Thirteen items were designed to assess the level of the ELC and 10 items to assess the ILC. The score for the ILC subscale can be in the range of 10 to 50 points and that for the ELC scale in the range of 13 to 65 points. The authors acknowledged that contentdependent scales for specific domains are emerging-academic, social, political-cultural, work-related, and others-but their use does not allow generalisation of the results.

The I-E Scale in Gliszczyńska's (1990) work, very similarly to Rotter's scale, consisted of 25 pairs of alternative statements with mandatory selections. In each pair, one statement indicates an ILC and the other an ELC. The tool enables consideration of the general aspect of the LOC called "life philosophy" (based on 12 philosophical questions) and the situational LOC termed "work situation" (based on questions concerning specific work situations). Unlike the author of the scale, Parys (2018) did not consider it justified to group the results of the two scales into one value.

Trice's (1985) Academic Locus of Control tool has a true or false format and detects students' beliefs in personal control over academic outcomes. The questions concern a variety of areas related to academic success and control orientations, such as chance, effort, ability, and influence by powerful others.

The Zemanová Dolejš Locus of Control Scale (Zemanová \& Dolejš, 2016) was utilised as the tool for this research. It is designed to examine and determine the LOC (external/internal) in adolescents and map beliefs about their ability to control sources of reinforcement. The 12-item questionnaire is based on Rotter's (1966) theory of social learning and its administration requires approximately 5 minutes. Six items identify the degree of ILC, and six items are dedicated to ELC. It is not explicitly intended for the academic population but was used by the original authors for purposes such as examining the relationship between LOC and risk activities in Czech adolescents (Dolejš et al., 2019). 
The I, P, and C scales by Levenson (1973) have also been used in the conditions of school education. The scales distinguish three types of beliefs concerning an individual's control of events in their life, called internal control (I), control by a powerful other (P), and control by chance (C). The division of external space into two different types of control arose from the consideration that people who believe that the world is generally uncontrollable behave and think differently than those who believe that the world is organised but controlled by other, more powerful individuals (Pšeno \& Vavráková, 2015).

With the intention to create a questionnaire for measuring LOC in the academic environment, which would have only one dimension (ILC vs ELC) and be thematically included in the environment and time-saving, Procházka et al. (2014) prepared a seven-item tool. Three items relate to an ILC and four items relate to an ELC. Subjects express a degree of agreement/ disagreement with statements on a four-point scale. The value of the interval variable is the average of the respondent's answers; a higher score corresponds to an ELC and a lower score indicates an ILC.

Rose and Medway (1981) authored the Teacher Locus of Control (TLC) scale. This 28 -item forced-choice scale requires teachers to assign responsibility for student successes or failures by choosing between two competing explanations for the situations described. Half the items on the TLC scale describe situations of student success, while the other half describes failures. For each success situation, one explanation attributes the positive outcome internally to the teacher $(\mathrm{I}+)$, while the other assigns responsibility outside the teacher, usually to the students. Similarly, for each failure situation, one explanation gives an internal teacher attribution $(\mathrm{I}-)$, while the other blames external factors. The authors found that the TLC scale is a better predictor of teacher behaviour than Rotter's (1966) scale, probably because it is more related to a teaching context.

\section{The problem of tertiary students' LOC}

Research on tertiary students' LOC has frequently been conducted to reveal factors that predict their academic success and affect their motivation to study or pursue a future profession and their satisfaction with their studies. Academic success has been attributed to student factors as well as teaching factors. Intrinsic factors comprise mainly self-management (taking responsibility, dealing with setbacks, self-awareness), motivation (short- and long-term goals, interest in the subject, willingness to learn, and personal skills), professionalism, communication, and workload management; extrinsic factors include teaching provision and support (Cachia et al. 2018). Strelnicki et al. (2015) considered self-efficacy, self-rated abilities, extraversion, openness 
to experience, and LOC as central components of students' personal characteristics important to post-secondary success. Students who are more likely to drop out typically exhibit an ELC. The authors surveyed 1,427 Canadian students, with an average age of 21, asking for a 5 -word description of what helped them to achieve their goals and 5 words about what kept them from achieving them. Of the total 6,446 responses, 157 students (i.e. 11\%) stated that their internal control (e.g. confidence, belief, pride) helped them. The internal control factor ranked $12^{\text {th }}$ in the frequency of student responses. In the second phase of the research, 19 master's students in educational psychology used the Q-sort methodology to select 20 word clusters for factors related to achieving the goals and 19 clusters for factors related to keeping students from reaching them. One-third of these students ranked internal control first among the 20 factors. A total of $47.4 \%$ of the Q-sort participants included among factors preventing the achievement of goals self-deprecation (words such as self-doubt, self-defeating, overconfident) and external support (e.g. no support, pressure, dependent), which are close to ELC.

With the help of an expert team, Kim et al. (2010) compiled an inventory of 62 items related to personal factors impacting college students' success, grouped them into 6 categories (motivation, self-confidence, support, emotional impact, and involvement), and had them evaluated by 597 students at a Midwestern university using a five-point Likert scale. Factor analysis identified six factors: academic self-efficacy (including confidence in academic ability, expectations, and awareness of effort toward study), organisation and attention to study, stress and time pressure, involvement in college activity, emotional satisfaction, and class communication. The highest correlation $(R=0.53)$ was measured between academic self-efficacy and emotional satisfaction. The academic self-efficacy factor comprised properties such as confidence and awareness of effort toward study, which are signs of an ILC.

Fraser and Killen (2003, p. 255) asked 675 full-time students at the University of Pretoria the following question: "What five factors or variables related to (a) staff teaching and (b) student learning have, according to you, the most important influence on your academic performance or achievement at university?" A similar question was asked of 61 lecturers at the Faculty of Education. Self-confidence was $5^{\text {th }}$ among first-year students in terms of importance, $7^{\text {th }}$ among final-year students, and $25^{\text {th }}$ among lecturers. Selfmotivation was the most important for final-year students and lecturers, but for first-year students it was students' interest in the course.

Bodill and Roberts (2013) attempted to verify whether implicit theories of intelligence and academic LOC are predictors of studying behaviour and stated that their study partially supported the proposition that implicit theories of intelligence were associated with LOC. Entity beliefs about intelligence 
were significantly positively associated with an ELC. Only academic LOC was a significant predictor of study behaviour in the university students studied.

Mohamed et al. (2018) measured LOC in two groups of nursing students using the Academic Locus of Control Scale (Curtis \& Trice, 2013). They determined that $75.2 \%$ of students in the experimental group had an ILC and only $14.4 \%$ of the control group had an ELC. The experimental group underwent a specific program aimed at increasing their ILC. The authors verified significant relationships between the age of the experimental group and their ILC and ELC for the training program. In contrast, there were no significant relationships between other socio-demographic characteristics (marital status, family income) and ILC and ELC. However, significant relationships were observed between gender, working conditions, number of working hours per day, whether they worked more than one shift, and whether they worked the night shift and their ILC and ELC after programme implementation.

Fazey and Fazey (2001) analysed factors potentially leading to learning autonomy - age, sex-related perception of competence, self-esteem, motivation, and LOC. The results indicated a favourable profile for new students, with motivation at the internalised end of the spectrum and a perceived ILC. Using a rotation of factors showed that the appearance of intrinsic motivation, ILC, and introjected regulation in one factor is of interest. The authors stated that the relationship between intrinsic motivation and ILC was not theoretically surprising as highly internalised motivation for studying (intrinsic motivation) — choosing to study for personal reasonslogically suggests that students perceive that they are in control of their successes and failures.

Řehulková (2007) researched the relationships between cognitive style, study style, and locus of personality control and determined that internality has positive relationships with field dependence (as a dimension of the concept of cognitive style) and positive factors of study style. Poziemska (2015) used the terms LOC in case of success and LOC in case of failure in the analysis of the perceptions of an individual's control over school events and results. Several studies (Moses, et al., 2011, cited by Strelnicki, et al., 2015) have concluded that openness and LOC also correlate with retention.

In the Czech academic environment, Procházka et al. (2014) explored the LOC of university students concerning their procrastination. They failed to show that the internality/externality of the LOC correlated with academic procrastination. However, some previous foreign studies have found differences in the degree of academic procrastination between groups of students with a more ILC and those with a more ELC. 
An equally important issue in the study of LOC in the academic environment is the possibility of influencing the LOC from externality to internality, showing positive correlations with academic success and retention. Walczak and Wężowska (2017) compared students who played role-playing games with those who were not interested in them and found that the players had a more ILC and a lower level of neuroticism in comparison with non-players. However, they acknowledged that this finding would need to be verified by further research. In the aforementioned experiment, Mohamed et al. (2018) increased the proportion of students in the experimental group with an ILC from $75.2 \%$ to $79.2 \%$.

Pšeno and Vavráková (2015) contributed to a more in-depth look at the process of LOC research by analysing a sample of almost 100 students. The research question was whether or to what extent the family as a primary educational environment affects the inclusion of an individual in one of the LOC types or its level. They used the I, P, and C scales by Levenson (1973) and the Parental Authority Questionnaire and found that authoritarian education (education in which parents provide a clear direction and rules are justified, but the parent is warm, flexible, and open to compromise; with the other types being authoritarian-irresponsive and liberal) from both father and mother can be considered as one of the factors contributing to a child's internality, with a possible positive effect from the father's care.

Wolinsky et al. (2009) examined the possibility of improving ILC with the Advanced Cognitive Training for Independent and Vital Elderly trial for adults aged 65 and above. The subjects were divided into four groups: memory, reasoning, speed of processing (intervention group), and no-contact control groups. They used a reduced (12-item) version of the Levenson (1973) tool to measure LOC and found that statistically significant effects reflecting medium-sized ( $S D \geq 0.5)$ improvements in ILC between the baseline and 5 -year follow-up were found for the reasoning and speed of processing intervention groups, who were $76 \%(p<0.01)$ and $68 \%(p<0.05)$ more likely, respectively, to improve than the no-contact control group. No improvement effects were found for the chance or powerful other LOC measures or for the memory intervention group.

Therapy, training, and courses aimed at increasing ILC levels (or transfer from the category of externalist to the category of internalist) are essential in terms of retention, defined, for example, as a student's decision to remain in their studies, which, from the university's point of view, means keeping the student in their studies, as noted by Švec \& Koláčková (2013). These authors stated that, unlike other European countries, the concept of retention is not officially defined in the Czech Republic, and there is no recognised way of calculating it. Five leading causes for non-traditional students to drop out of universities have been identified: learning outcomes, intention to leave 
school, past performance, educational goals, and environmental variables (e.g. finances, working hours, parental responsibilities, etc.; Bean \& Metzner, 1985 in Švec \& Koláčková, 2013). These factors were later enriched with students' input characteristics (e.g. past behaviour, faith, perceptions of the university environment) and living within a university environment that evoked psychological processes of increasing performance, reducing stress, and increasing self-control (Bean \& Eaton, 2000). In our opinion, the increase in self-control can only be another name for ILC.

\section{LOC in education-oriented professions}

Requirements for professions in education include, in addition to professional competencies, certain personality traits that co-determine successful performance and the fulfilment of expected roles (Vašutová, 2004). However, among the usually stated requirements for these qualities, such as qualities of character and will (e.g. honesty, sincerity, bravery, justice, principledness, purposefulness, perseverance, determination, independence), work qualities (love and relationships with children and pedagogical work, consistency, conscientiousness), intellectual qualities (logic, creative thinking), emotionaltemperamental qualities (optimism, patience, self-control), and socialcharacter qualities (kindness, cordiality, decency, consideration, respectfulness, understanding). It is not possible to find a demand for LOC.

A growing interest in the relationship between LOC and other factors affecting the performance or satisfaction of teachers can be found in numerous studies. Betoret (2013) verified that:

The teachers who believe that their professional development depends mainly on their own behaviour and actions are strongly involved at work, and experience a sense of significance, enthusiasm and pride. Conversely, those teachers who believe that "There's nothing they can do" toward their professional development are little involved at work. According to these results, we can assert that locus of control moderates the relationship between teacher needs and dedication. Therefore, the data obtained support the hypothesized moderation role played by locus of control in the relationship between psychological needs and dedication (one of the components of engagement). (p. 10)

Mahajan and Kaur (2012) revealed a significant relationship between college teachers' LOC and their job satisfaction. The fact that job satisfaction can be significantly predicted by the LOC is valid also for schoolteachers (Basak \& Ghosh, 2011).

Akkaya and Akyol (2016) found that teachers' perception of ILC is lower than their perception of LOC based on others and luck/faith. 
Akca et al. (2018) tested relationships among self-efficacy beliefs, LOC, and intercultural sensitivities among teachers. They found a positive connection between the level of intercultural sensitivity and the level of LOC ( $R=0.436, p<0.01)$, and it can be concluded that the level of intercultural sensitivity was higher with individuals having a high level of LOC than with individuals having a low level of LOC. Another finding related to a positive and significant relationship between self-efficacy beliefs and LOC $(R=0.447, p<0.01)$. It can be concluded that the self-efficacy beliefs of the individuals with high LOC levels were higher than those with low LOC levels. Finally, self-efficacy beliefs and cross-cultural susceptibility variables showed a significant relationship $\left(R=0.543, R^{2}=0.295\right)$ with cross-cultural susceptibility. The two variables together accounted for $30 \%$ of the change in LOC, and they were significant predictors of LOC.

The conclusions of Toussi and Ghanizadeh (2012) indicated a significant relationship between teachers' self-regulation and ILC. They found that about $48 \%$ of the variation in teacher self-regulation could be explained by taking their ILC into account. They recommended that teacher educators take advantage of this relationship by providing teachers with programmes and experiences for developing efficient paths for enhancing teacher selfregulatory skills as well as their internal tendencies and perceptions.

Examining the relationship between the LOC and innovation in special pedagogues, Parys (2018) found that people with a high perception of ILC showed a higher level of innovation in teaching than people with low or average levels of control. For the life philosophy scale, the indicator of this variance was close to statistical significance $(p=0.06)$, while statistical significance was not found for the work situation scale.

Research on the relationship between teachers' LOC and different variables brought interesting results in a study by Kiral (2019). Teachers mostly exhibited ILC followed by ELC and chance LOC (classification according to Levenson, 1973). There were no significant differences between teachers' LOC and their gender, marital status, length of service at the school, or love for the profession. In contrast, the teachers' LOC exhibited significant differences according to their age, seniority, and teaching speciality and the school's socio-economic status.

\section{Research problem, objectives, variables, and hypotheses}

The research problem is the absence of a convincing distribution of students (at the examined faculties and in general) according to their LOC in a bidimensional concept, i.e. according to the prevailing values of internality and externality, with respect to the division of students into traditional (full-time) 
and non-traditional (part-time). The ways in which other characteristics of non-traditional students moderate the distribution are also yet to be identified. The empirical part of study aims to determine the relative frequencies of non-traditional students in the categories of students with a predominant ILC (ILC as major) and students with a predominant ELC (ELC as major) in comparison with traditional students and verify whether for non-traditional (part-time) students this division is influenced by gender, tertiary education level (type of study), year of study, whether the respondent is studying in the final year of the programme (phase of study), or age.

The main research variables are the level of ILC and the level of ELC in accordance with the theoretical concept and the relevant assessment tool. The moderating variables include the form of study, the type of study, the year of study, the phase of study, gender, and age.

The research tool enables assessment of both LOC values for each subject (assuming that they are not identical). For each subject, the higher discovered value can always be considered as the main, important factor (major) and the lower discovered value as the secondary, less important factor (minor). According to the predominant LOC value, students can be divided into two main groups: students with ILC as major and students with ELC as major.

Six research questions arose from the elaboration of the research problem and the assumed relationships of the research variables.

1 Do non-traditional students differ from traditional students in their division into the ILC and ELC categories?

2 Do non-traditional students differ by gender in their division into the ILC and ELC categories?

3 Do non-traditional students differ according to their type of study in their division into the ILC and ELC categories?

4 Is it possible to find differences in the study group of non-traditional students divided according to the phase of study (final year of study vs. other years) in their division into the ILC and ELC categories?

5 Does the division of non-traditional students into the ILC and ELC categories change according to the year of study?

6 What is the division of non-traditional students into the ILC and ELC categories according to specified age groups?

Due to the two dimensions of LOC-ILC and ELC - it was necessary to statistically test the relationships of both LOC dimensions with all moderating variables. Thus, 6 pairs of hypotheses (12 in total) were formulated (marked $1 \mathrm{a} H-6 \mathrm{a} H, 1 \mathrm{bH}-6 \mathrm{~b} H)$. The hypotheses are presented before the respective results in the Results section for greater clarity and economy of the text. 


\section{Method}

The Zemanová Dolejš Locus of Control Scale was used to measure LOC (Zemanová \& Dolejš, 2016). It is not intended specifically for the academic population, but for adolescents in general. Choosing an answer does not take much time and the items are well understood by students. The six items indicating an ILC are: I do not give up easily. I have my life firmly in my hands. I believe. When I encounter an obstacle, I believe I will overcome it. I always have control over what I do. I have to try if I want to achieve what I want. The six items indicating an ELC are: I have little control over what happens in my life. I'm often unlucky. I make the decisions I make because someone else wanted to. I get one blow after another from life. I often find that my life is controlled by others. I can't decide. For each question, the following scale was applied: 1 - strongly disagree, 2 - rather disagree, 3 - rather agree, 4 - strongly agree. The reliability of the proposed research tool was determined by Cronbach's alpha as 0.603 for all participants and 0.602 for part-time respondents.

\section{Sample, data collection, and statistical processing}

A total of 411 university students from the Faculty of Education at the University of Ostrava took part in the survey. Of these, 259 participants (63\%) were fulltime students and 152 participants (37\%) were part-time students. The study involved $332(81.5 \%)$ women and $76(18.5 \%)$ men. Data collection took place in April 2020 in the form of an online questionnaire. All students in bachelor's, post-bachelor's, and master's study programmes (i.e. 1,793 students) were asked to fill it in. The share of non-traditional students (those studying part-time) was $38 \%$ and the share of traditional students was $62 \%$. A total of $22.9 \%$ of all students at the faculty took part in the survey. Form of study (full-time/part-time), type of study (bachelor's studies, post-bachelor's studies, master's studies), year of study $\left(1^{\text {st }}-5^{\text {th }}\right)$, gender (male, female), and age were identified for each respondent as nominal (categorical) statistical variables.

The statistical processing was carried out in the statistical software IBM SPSS Statistics and PAST Statistics (Hammer et al., 2001). For statistical research processing, quantitative techniques (Gauthier \& Hawley, 2015; Kitchenham et al., 2017) were used as can be found in similar applied research with consideration of statistical significance (e.g. Barot et al., 2020; Lacková, 2014). 


\section{Results}

A total of 364 students had ILC as major, with an average value of 3.17. Then, 47 students exhibited ELC as major, with an average value of 2.77. Since each respondent obtained two average values, for ILC and ELC, pairs of research questions are introduced.

\section{Q1 Relationship to the form of study (full-time $\times$ part-time)}

Research question Q1a: Was there a statistically significant relationship between the average values for students with ILC as major and the form of study? Research question Q1b: Was there a statistically significant relationship between the average values for students with ELC as major and the form of study? Hypotheses $1 \mathrm{a} H$ and $1 \mathrm{bH}$ were tested for these questions.

$1 \mathrm{a} H_{\mathrm{A}}$ : There was a statistically significant relationship between the average values for students with ILC as major and the form of study (full-time or part-time).

For hypothesis $1 \mathrm{aH}, p=4.825 \times 10^{-4}$ (i.e. $\left.<0.001\right)$ using the Mann-Whitney test. Therefore, the null hypothesis can be rejected in favour of alternative hypothesis $1 \mathrm{a} H_{\mathrm{A}}$ at the significance level of 0.001 . A statistically significant relationship was found between the average values for students with ILC as major and the form of study.

$1 \mathrm{~b} H_{\mathrm{A}}$ : There was a statistically significant relationship between the average values for students with ELC as major and the form of the study (full-time or part-time).

For hypothesis $1 \mathrm{bH}, p=1.789 \times 10^{-3}$ (i.e. $<0.01$ ) using the Mann-Whitney test. Therefore, the null hypothesis can be rejected in favour of alternative hypothesis $1 \mathrm{~b} H_{\mathrm{A}}$ at the significance level of 0.01 . A statistically significant relationship was found between the average values for students with an ELC as major and the form of study.

Table 1 presents the distribution of the occurred frequencies and averages for both forms of study.

Table 1

Classification of ILC and ELC as major and general identification without any relationship to the form of study-achieved frequencies and means ( $\mathrm{n}=411)$

\begin{tabular}{|l|c|c|c|c|c|}
\hline & \multicolumn{2}{|c|}{ Frequencies } & \multicolumn{2}{c|}{ Averages } \\
\hline ILC as major & ELC as major & Sample size & $\begin{array}{c}\text { ILC major } \\
\text { and minor }\end{array}$ & $\begin{array}{c}\text { ELC major } \\
\text { and minor }\end{array}$ \\
\hline Full-time & $\begin{array}{c}226 \text { of } 259 \\
(87.26 \%)\end{array}$ & $\begin{array}{c}33 \text { of } 259 \\
(12.74 \%)\end{array}$ & $\begin{array}{c}259 \text { of } 411 \\
(63.02 \%)\end{array}$ & 3.03 & 3.19 \\
\hline Part-time & $\begin{array}{c}138 \text { of } 152 \\
(90.79 \%)\end{array}$ & $\begin{array}{c}14 \text { of } 152 \\
(9.21 \%)\end{array}$ & $\begin{array}{c}152 \text { of } 411 \\
(39.98 \%)\end{array}$ & 2.00 & 1.84 \\
\hline $\begin{array}{l}\text { Independent } \\
\text { of form of study }\end{array}$ & $\begin{array}{c}364 \text { of } 411 \\
(88.56 \%)\end{array}$ & $\begin{array}{c}47 \text { of } 411 \\
(11.44 \%)\end{array}$ & 411 & 3.17 & 2.77 \\
\hline
\end{tabular}




\section{Q2 Relationship to gender (male $\times$ female), part-time students}

Research question Q2a: Was there a statistically significant relationship between the average values for part-time students with ILC as major and gender? Research question Q2b: Was there a statistically significant relationship between the average values for part-time students with ELC as major and gender? For these questions, hypotheses $2 \mathrm{a} H$ and $2 \mathrm{bH}$ were tested.

$2 \mathrm{aH}_{\mathrm{A}}$ : There was no statistically significant relationship between the average values for part-time students with ILC as major and gender (male or female).

For hypothesis $2 \mathrm{a} H, p=0.0166$ (i.e. $<0.05$ ) using the Mann-Whitney test. Therefore, the null hypothesis can be rejected in favour of alternative hypothesis $2 \mathrm{a} H_{\mathrm{A}}$ at the significance level of 0.05 . A statistically significant relationship was found between the average values for part-time students with ILC as major and gender.

$2 \mathrm{bH} H_{\mathrm{A}}$ : There was a statistically significant relationship between the average values of the part-time students with ELC as major and gender (male or female).

For hypothesis $2 \mathrm{bH}, p=0.0586$ (i.e. $>0.05$ ) using the Mann-Whitney test. Therefore, the null hypothesis could not be rejected at the significance level of 0.05 . No statistically significant relationship was found between the average values for part-time students with ELC as major and gender.

Table 2 presents the distribution of the frequencies and averages for gender.

Table 2

Classification of ILC and ELC as major and general identification without any relationship to gender-achieved frequencies and arithmetical averages (part-time students: $\mathrm{n}=152$ )

\begin{tabular}{|l|c|c|c|c|c|}
\hline & \multicolumn{2}{|c|}{ Frequencies } & & \multicolumn{2}{c|}{ Averages } \\
\hline Male & ILC as major & ELC as major & Sample size & $\begin{array}{c}\text { ILC major } \\
\text { and minor }\end{array}$ & $\begin{array}{c}\text { ELC major } \\
\text { and minor }\end{array}$ \\
\hline Female & $\begin{array}{c}32 \text { of } 35 \\
(91.43 \%)\end{array}$ & $\begin{array}{c}3 \text { of } 35 \\
(8.57 \%)\end{array}$ & $\begin{array}{c}35 \text { of } 152 \\
(23.03 \%)\end{array}$ & 3.32 & 1.71 \\
\hline $\begin{array}{l}\text { Independent } \\
\text { of gender }\end{array}$ & $\begin{array}{c}138 \text { of } 117 \\
(90.6 \%)\end{array}$ & $\begin{array}{c}11 \text { of } 117 \\
(9.4 \%)\end{array}$ & $\begin{array}{c}117 \text { of } 152 \\
(76.97 \%)\end{array}$ & 3.14 & 1.88 \\
\hline
\end{tabular}

Q3 Relationship to the type of study (bachelor's studies $\times$ post-bachelor's studies), part-time students

Research question Q3a: Was there a statistically significant relationship between the average values for part-time students with ILC as major and the type of study? Research question Q3b: Was there is a statistically significant relationship between the average values for part-time students with ELC as major and the type of study? For these questions, hypotheses $3 \mathrm{aH}$ and $3 \mathrm{bH}$ were tested. 
$3 \mathrm{a} H_{\mathrm{A}}$ : There was a statistically significant relationship between the average values for part-time students with ILC as major and the type of study (bachelor's or post-bachelor's). For hypothesis $3 \mathrm{aH}, p=0.339$ (i.e. > 0.05) using the Mann-Whitney test. Therefore, the null hypothesis could not be rejected at the significance level of 0.05 . No statistically significant relationship was found between the average values for part-time students with ILC as major and the type of study.

$3 \mathrm{~b} H_{\mathrm{A}}$ : There was a statistically significant relationship of the average values for parttime students with ELC as major and the type of study (bachelor's or post-bachelor's). For hypothesis $3 \mathrm{bH}, p=0.3531$ (i.e. $>0.05$ ) using the Mann-Whitney test. Therefore, the null hypothesis could not be rejected at the significance level of 0.05 . No statistically significant relationship was found between the average values for part-time students with ELC as major and the type of study.

Table 3 presents the distribution of the occurred frequencies and averages for both types of study.

Table 3

Classification of ILC and ELC as major and general identification without any relationship to the type of study - achieved frequencies and arithmetical averages (part-time students, bachelor's and post bachelor's: $\left.\mathrm{n}=134^{*}\right)$.

\begin{tabular}{|l|c|c|c|c|c|}
\hline & \multicolumn{2}{|c|}{ Frequencies } & \multicolumn{2}{c|}{ Averages } \\
\hline & ILC as major & ELC as major & Sample size & $\begin{array}{c}\text { ILC major } \\
\text { and minor }\end{array}$ & $\begin{array}{c}\text { ELC major } \\
\text { and minor }\end{array}$ \\
\hline bachelor's & $\begin{array}{c}86 \text { of } 98 \\
(87.76 \%)\end{array}$ & $\begin{array}{c}12 \text { of } 98 \\
(12.24 \%)\end{array}$ & $\begin{array}{c}98 \text { of } 134 \\
(73.13 \%)\end{array}$ & 3.15 & 1.87 \\
\hline post-bachelor's & $\begin{array}{c}34 \text { of } 36 \\
(94.44 \%)\end{array}$ & $\begin{array}{c}2 \text { of } 36 \\
(5.56 \%)\end{array}$ & $\begin{array}{c}36 \text { of } 134 \\
(26.87 \%)\end{array}$ & 3.25 & 1.78 \\
\hline $\begin{array}{l}\text { Independent } \\
\text { of type of study }\end{array}$ & $\begin{array}{c}120 \text { of } 134 \\
(89.55 \%)\end{array}$ & $\begin{array}{c}14 \text { of } 134 \\
(10.45 \%)\end{array}$ & 134 & 3.18 & 1.85 \\
\hline
\end{tabular}

* This categorisation could not be used for 18 master's students studying in a continuous five-year programme; therefore, the total number of non-traditional students was reduced by this number.

Q4 Relationship to the phase of study (final years $\times$ non-final years), part-time students For the data processing, the following combinations were considered as the final years of study: final year of study ( $3^{\text {rd }}$ year in bachelor's study programmes, $2^{\text {nd }}$ year in post-bachelor's study programmes, $5^{\text {th }}$ year in master's study programmes) and non-final years of study $\left(1^{\text {st }}-2^{\text {nd }}\right.$ years in bachelor's study programmes, $1^{\text {st }}$ year in post-bachelor's study programme, $1^{\text {st }}-4^{\text {th }}$ years in master's study programmes), as can be seen in Table 4 . 
Table 4

Phase of study according to study years ( $B$ - bachelor's, $P$ - post-bachelor's, $M$ - master's)

\begin{tabular}{|c|c|c|c|c|c|c|c|c|l|}
\hline \multicolumn{7}{|c|}{ Non-final years of study } & \multicolumn{3}{c|}{ Final years of study } \\
\hline $1^{\text {st }} \mathrm{B}$ & $2^{\text {nd }} \mathrm{B}$ & $1^{\text {st }} \mathrm{P}$ & $1^{\text {st }} \mathrm{M}$ & $2^{\text {nd }} \mathrm{M}$ & $3^{\text {rd }} \mathrm{M}$ & $4^{\text {th }} \mathrm{M}$ & $3^{\text {rd }} \mathrm{B}$ & $2^{\text {nd }} \mathrm{P}$ & $5^{\text {th }} \mathrm{M}$ \\
\hline 33 & 27 & 16 & 1 & 7 & 4 & 4 & 38 & 20 & 2 \\
\hline$(21.71 \%)$ & $(17.76 \%)$ & $(10.53 \%)$ & $(0.66 \%)$ & $(4.61 \%)$ & $(2.63 \%)$ & $(2.63 \%)$ & $(25 \%)$ & $(13.16 \%)$ & $(1.32 \%)$ \\
\hline \multicolumn{8}{|c|}{92} & \multicolumn{4}{c|}{60} \\
\hline \multicolumn{8}{|c|}{$(60.53 \%)$} & $39.47 \%)$ \\
\hline
\end{tabular}

Research question Q4a: Was there a statistically significant relationship between the average values for part-time students with ILC as major and the phase of study? Research question Q4b: Was there a statistically significant relationship between the average values for part-time students with ELC as major and the phase of study? For these questions, hypotheses $4 \mathrm{a} H$ and $4 \mathrm{bH}$ were tested.

$4 \mathrm{aH}_{\mathrm{A}}$ : There was a statistically significant relationship between the average values for part-time students with ILC as major and the phase of study (final or non-final years). For hypothesis $4 \mathrm{aH}, \mathrm{p}=0.2851$ (i.e. > 0.05) using the Mann-Whitney test. Therefore, the null hypothesis could not be rejected at the significance level of 0.05 . No statistically significant relationship was found between the average values for part-time students with ILC as major and the phase of study.

$4 \mathrm{bH}_{\mathrm{A}}$ : There was a statistically significant relationship between the average values for part-time students with ELC as major and the phase of study (final or non-final years). For hypothesis 4bH, $p=0.9214$ (i.e. $>0.05$ ) using the Mann-Whitney test. Therefore, the null hypothesis could not be rejected at the significance level of 0.05 . No statistically significant relationship was found between the average values for part-time students with ELC as major and the phase of study.

Table 5 presents the distribution of the occurred frequencies and averages for both phase.

Table 5

Classification of ILC and ELC as major and general identification without any relationship to the phase of study — achieved frequencies and arithmetical averages (part-time students: $\mathrm{n}=152$ )

\begin{tabular}{|l|c|c|c|c|c|}
\hline & \multicolumn{2}{|c|}{ Frequencies } & & \multicolumn{2}{c|}{ Averages } \\
\hline & ILC as major & ELC as major & Sample size & $\begin{array}{c}\text { ILC major } \\
\text { and minor }\end{array}$ & $\begin{array}{c}\text { ELC major } \\
\text { and minor }\end{array}$ \\
\hline Final years & $\begin{array}{c}52 \text { of } 60 \\
(86.67 \%)\end{array}$ & $\begin{array}{c}8 \text { of } 60 \\
(13.33 \%)\end{array}$ & $\begin{array}{c}60 \text { of } 152 \\
(39.47 \%)\end{array}$ & 3.14 & 1.85 \\
\hline Non-final years & $\begin{array}{c}86 \text { of } 92 \\
(93.48 \%)\end{array}$ & $\begin{array}{c}6 \text { of } 92 \\
(6.52 \%)\end{array}$ & $\begin{array}{c}92 \text { of } 152 \\
(60.53 \%)\end{array}$ & 3.21 & 1.83 \\
\hline $\begin{array}{l}\text { Independent } \\
\text { of phase of study }\end{array}$ & $\begin{array}{c}138 \text { of } 152 \\
(90.79 \%)\end{array}$ & $\begin{array}{c}14 \text { of } 152 \\
(9.21 \%)\end{array}$ & 152 & 3.19 & 1.84 \\
\hline
\end{tabular}


Q5 Relationship to the year of study $\left(1^{s t}-5^{\text {th }}\right.$ year $)$, part-time students

The years of study were unified according to the type of study, as can be seen in Table 6.

Table 6

Years of study unification according to the type of study (B - bachelor's, $P$ - post-bachelor's, $M-$ master's)

\begin{tabular}{|c|c|c|c|c|}
\hline \multicolumn{2}{|l|}{ Bachelor's study programme } & \multicolumn{2}{c|}{ Post-bachelor's study programme } \\
\hline $1^{\text {st }} \mathrm{B}$ & $2^{\text {nd }} \mathrm{B}$ & $3^{\text {td }} \mathrm{B}$ & $1^{\text {st }} \mathrm{P}$ & $2^{\text {nd }} \mathrm{P}$ \\
\hline $1^{\text {st }} \mathrm{M}$ & $2^{\text {nd }} \mathrm{M}$ & $3^{\text {rd }} \mathrm{M}$ & $4^{\text {th }} \mathrm{M}$ & $5^{\text {th }} \mathrm{M}$ \\
\hline
\end{tabular}

Research question Q5a: Was there a statistically significant relationship between the average values for part-time students with ILC as major and the year of study? Research question Q5b: Was there a statistically significant relationship between the average values for part-time students with ELC as major and the year of study? For these questions, hypotheses $5 \mathrm{a} H$ and $5 \mathrm{~b} H$ were tested.

$5 \mathrm{aH}_{\mathrm{A}}$ : There was a statistically significant relationship between the average values for part-time students with ILC as major and the year of study $\left(1^{\text {st }}-5^{\text {th }}\right.$ year).

For hypothesis $5 \mathrm{aH}, p=0.1969$ (i.e. > 0.05) using the Kruskal-Wallis test. Therefore, the null hypothesis could not be rejected at the significance level of 0.05 . No statistically significant relationship was found between the average values for part-time students with ILC as major and the year of study.

$5 \mathrm{~b} H_{\mathrm{A}}$ : There was a statistically significant relationship between the average values for part-time students with ELC as major and the year of study $\left(1^{\text {st }}-5^{\text {th }}\right.$ year $)$.

For hypothesis $5 \mathrm{bH}, p=0.6202$ (i.e. $>0.05$ ) using the Kruskal-Wallis test. Therefore, the null hypothesis could not be rejected at the significance level of 0.05. No statistically significant relationship was found between the average values for part-time students with ELC as major and the year of study.

Table 7 presents the distribution of the occurred frequencies and averages for years of study. 
Table 7

Classification of ILC and ELC as major and general identification without any relationship to year of study - achieved frequencies and arithmetical averages (part-time students: $\mathrm{n}=152$ )

\begin{tabular}{|l|c|c|c|c|c|}
\hline & \multicolumn{2}{|c|}{ Frequencies } & \multicolumn{2}{c|}{ Averages } \\
\hline & ILC as major & ELC as major & Sample size & $\begin{array}{c}\text { ILC major } \\
\text { and minor }\end{array}$ & $\begin{array}{c}\text { ELC major } \\
\text { and minor }\end{array}$ \\
\hline $1^{\text {st }}$ year of study & $\begin{array}{c}44 \text { of } 47 \\
(93.62 \%)\end{array}$ & $\begin{array}{c}3 \text { of } 47 \\
(6.38 \%)\end{array}$ & $\begin{array}{c}47 \text { of } 152 \\
(30.92 \%)\end{array}$ & 3.18 & 1.87 \\
\hline $2^{\text {nd }}$ year of study & $\begin{array}{c}43 \text { of } 48 \\
(89.58 \%)\end{array}$ & $\begin{array}{c}5 \text { of } 48 \\
(10.42 \%)\end{array}$ & $\begin{array}{c}48 \text { of } 152 \\
(31.58 \%)\end{array}$ & 3.23 & 1.79 \\
\hline $3^{\text {rd }}$ year of study & $\begin{array}{c}36 \text { of } 42 \\
(85.71 \%)\end{array}$ & $\begin{array}{c}6 \text { of } 42 \\
(14.29 \%)\end{array}$ & $\begin{array}{c}42 \text { of } 152 \\
(27.63 \%)\end{array}$ & 3.08 & 1.89 \\
\hline $4^{\text {th }}$ year of study & $\begin{array}{c}7 \text { of } 7 \\
(100 \%)\end{array}$ & $\begin{array}{c}0 \text { of } 7 \\
(0 \%)\end{array}$ & $\begin{array}{c}7 \text { of } 152 \\
(4.61 \%)\end{array}$ & 3.36 & 1.86 \\
\hline $5^{\text {th }}$ year of study & $\begin{array}{c}8 \text { of } 8 \\
(100 \%)\end{array}$ & $\begin{array}{c}0 \text { of } 8 \\
(0 \%)\end{array}$ & $\begin{array}{c}8 \text { of } 152 \\
(5.26 \%)\end{array}$ & 3.31 & 1.65 \\
\hline $\begin{array}{l}\text { Independent } \\
\text { of year of study }\end{array}$ & $\begin{array}{c}138 \text { of } 152 \\
(90.79 \%)\end{array}$ & $\begin{array}{c}14 \text { of } 152 \\
(9.21 \%)\end{array}$ & 152 & 3.19 & 1.84 \\
\hline
\end{tabular}

\section{Q6 Relationship to age category, part-time students}

Student ages were classified into 7 categories at intervals of 5 years: $1^{\text {st }}$ age category (up to 25), $2^{\text {nd }}$ age category (26-30), $3^{\text {rd }}$ age category (31-35), $4^{\text {th }}$ age category $(36-40), 5^{\text {th }}$ age category (41-45), $6^{\text {th }}$ age category (46-50), and $7^{\text {th }}$ age category (51 and above).

Research questions Q6a: Was there a statistically significant relationship between the average values for part-time students with ILC as major and the defined age categories? Research Question Q6b: Was there a statistically significant relationship between the average values for part-time students with ELC as major and the defined age categories? For these questions, hypotheses $6 \mathrm{aH}$ and $6 \mathrm{bH}$ were tested.

$6 \mathrm{a} H_{\mathrm{A}}$ : There was a statistically significant relationship between the average values for part-time students with ILC as major and the declared age categories.

For hypothesis $6 a H, p=0.772$ (i.e. $>0.05$ ) using the Kruskal-Wallis test. Therefore, the null hypothesis could not be rejected at the significance level of 0.05 . No statistically significant relationship was found between the average values for part-time students with ILC as major and the declared age categories.

$6 \mathrm{bH} H_{\mathrm{A}}$ : There was a statistically significant relationship between the average values for part-time students with ELC as major and the declared age categories.

For hypothesis $6 \mathrm{bH}, p=0.611$ (i.e. $>0.05$ ) using the Kruskal-Wallis test. Therefore, the null hypothesis could not be rejected at the significance 
level of 0.05 . No statistically significant relationship was found between the average values for part-time students with ELC as major and the declared age categories.

Table 8 presents the distribution of the occurred frequencies and averages for age categories.

Table 8

Classification of ILC and ELC as major and general identification without any relationship to age categories—achieved frequencies and arithmetical averages (part-time students: $n=152$ )

\begin{tabular}{|l|c|c|c|c|c|}
\hline & \multicolumn{2}{|c|}{ Frequencies } & \multicolumn{2}{c|}{ Averages } \\
\hline & ILC as major & ELC as major & Sample size & $\begin{array}{c}\text { ILC major } \\
\text { and minor }\end{array}$ & $\begin{array}{c}\text { ELC major } \\
\text { and minor }\end{array}$ \\
\hline $\begin{array}{l}1^{\text {st }} \text { age category } \\
\text { (up to } 25)\end{array}$ & $\begin{array}{c}37 \text { of } 44 \\
(84.09 \%)\end{array}$ & $\begin{array}{c}7 \text { of } 44 \\
(15.91 \%)\end{array}$ & $\begin{array}{c}44 \text { of } 152 \\
(28.95 \%)\end{array}$ & 1.77 & 2.62 \\
\hline $\begin{array}{l}2^{\text {nd }} \text { age category } \\
(26-30)\end{array}$ & $\begin{array}{c}34 \text { of } 37 \\
(91.89 \%)\end{array}$ & $\begin{array}{c}3 \text { of } 37 \\
(8.11 \%)\end{array}$ & $\begin{array}{c}37 \text { of } 152 \\
(24.34 \%)\end{array}$ & 1.71 & 2.61 \\
\hline $\begin{array}{l}3^{\text {rd }} \text { age category } \\
(31-35)\end{array}$ & $\begin{array}{c}13 \text { of } 13 \\
(100 \%)\end{array}$ & $\begin{array}{c}0 \text { of } 13 \\
(0 \%)\end{array}$ & $\begin{array}{c}13 \text { of } 152 \\
(8.55 \%)\end{array}$ & 3.24 & - \\
\hline $\begin{array}{l}4^{\text {th }} \text { age category } \\
(36-40)\end{array}$ & $\begin{array}{c}14 \text { of } 16 \\
(87.5 \%)\end{array}$ & $\begin{array}{c}2 \text { of } 16 \\
(12.5 \%)\end{array}$ & $\begin{array}{c}16 \text { of } 152 \\
(10.53 \%)\end{array}$ & 3.21 & 2.67 \\
\hline $\begin{array}{l}5^{\text {th }} \text { age category } \\
(41-45)\end{array}$ & $\begin{array}{c}20 \text { of } 21 \\
(95.24 \%)\end{array}$ & $\begin{array}{c}1 \text { of } 21 \\
(4.76 \%)\end{array}$ & $\begin{array}{c}21 \text { of } 152 \\
(13.82 \%)\end{array}$ & 3.33 & 2.50 \\
\hline $\begin{array}{l}6^{\text {th }} \text { age category } \\
(46-50)\end{array}$ & $\begin{array}{c}16 \text { of } 16 \\
(100 \%)\end{array}$ & $\begin{array}{c}0 \text { of } 16 \\
(0 \%)\end{array}$ & $\begin{array}{c}16 \text { of } 152 \\
(10.53 \%)\end{array}$ & 3.25 & - \\
\hline $\begin{array}{l}7^{\text {th }} \text { age category } \\
(51+)\end{array}$ & $\begin{array}{c}4 \text { of } 5 \\
(80 \%)\end{array}$ & $\begin{array}{c}1 \text { of } 5 \\
(20 \%)\end{array}$ & $\begin{array}{c}5 \text { of } 152 \\
(3.28 \%)\end{array}$ & 3.50 & 2.67 \\
\hline $\begin{array}{l}\text { Independent } \\
\text { of age category }\end{array}$ & $\begin{array}{c}138 \text { of } 152 \\
(90.79 \%)\end{array}$ & $\begin{array}{c}14 \text { of } 152 \\
(9.21 \%)\end{array}$ & 152 & 2.86 & 2.61 \\
\hline
\end{tabular}

\section{Discussion}

The LOC analysis for a specific subgroup of non-traditional tertiary students performed in this study yielded findings that are difficult to compare with the results of other research. The main reason is that when the LOC was analysed in previous research on tertiary students, there was no division into traditional and non-traditional students with regards to the form of study.

The remaining possibility is to compare the data for the students and especially the non-traditional students analysed in the research with the data for students without that attribute. It can be stated that in the entire sample of students at the faculty, the share of students with an ILC was $88.56 \%$ and the share of students with an ELC was $11.44 \%$. These numbers were different from the only available source (Mohamed et al., 2018), which had 
$75.2 \%$ for ILC students and $24.8 \%$ for ELC students. In our group, the share of at-risk students was significantly smaller.

If the same comparison were made only for non-traditional students, the difference would be even more evident $(90.79 \%$ for ILC students and 9.21\% for ELC students versus $75.2 \%$ and $24.8 \%$ for these categories).

In terms of gender, our group of non-traditional students had a slightly higher share of respondents of men with an ILC $(91.43 \%)$ compared to similar women $(90.6 \%)$. In the compared group of Egyptian nursing students, the situation was the reverse. The share of women with an ILC was $77.9 \%$ compared to $66.6 \%$ of the men. The somewhat unexpected figure for the male population was likely given by the type of vocational training preparing for a caring profession chosen by candidates with lower performance motivation or lower self-esteem.

Our research did not confirm the assumption that non-traditional students would possess a higher level of ILC and the greatest share of students with ILC as major would be in the final year of all study programmes. This assumption was based on the idea that at the end of their studies students would be more aware of the need and desire to deploy their strength to complete their studies with meaning for themselves, their family, and potentially employers. The mean values for ILC were slightly lower in the final year of study, however, as were the mean values for ELC. The relative frequency of students with ILC as major also decreased and the relative frequency of students with ELC as major logically increased. The uncertainty associated with the defence of final theses (bachelor's and master's theses), the uncertainty of the composition of their examination commissions, and other such unique and non-routine evaluation procedures with which students had not had any, or only one, experience may have played a role in this phenomenon.

In the fourth and fifth years of study, no students were found to have ELC as major and, conversely, all were characterised by ILC as major, although the total number of such students (15) was relatively small. Although no statistically significant relationship was found between the year of study and ILC or ELC, it is possible to consider that adults in the role of nontraditional students have developed adaptation mechanisms to cope with all learning tasks and situations with a strong presumption of retention and successful completion of their training over their previous years of study. Findings regarding an increase in the proportion of students with ELC as major from the first to the third year, which were not presented, will require further analysis.

The limits of this study focused on the LOC of non-traditional tertiary students can be seen in the not-yet-standardised or little-used national tool, which may limit the possibility or dissemination of research in other countries. 
Another possible limit lies in the fact that the scale used, despite its primary designation for adolescents, is neither status- (i.e. clearly intended for academic students) nor profession-specific (although LOC was examined in students preparing for educational professions). Nevertheless, the tool used showed a satisfactory level of Cronbach's alpha.

Further research possibilities can be seen in LOC detection in (not only non-traditional) tertiary students and monitoring the connection between LOC and certain other personality factors such as responsibility, stress resistance, performance motivation, academic success, and broad entrepreneurship.

\section{Conclusion}

In summary, it can be seen that the division of students into types of LOC was influenced by their form of study. The course of study at school had no or little effect on each of the two types of LOC in non-traditional students, which may signal that this psychological characteristic is relatively stable in the medium term (such as a student's time at university). At the same time, however, it turned out that the average level of ILC increased slightly with age, and in higher years of study the proportion of students with ILC increased. There was an apparent increase from the first to the third year in the share of students with ELC, and this proportion was then $0 \%$ in master's study programmes.

Out of all students, ELC was found in 47 students (11.44\%). This share was higher for full-time students (12.74\%) compared to non-traditional students $(9.21 \%)$. If this share applied to the basic group of all students at the faculty $(1,793)$, then there could have been about 230 externalist students, i.e. students who are at higher risk of study failure or dropping out. If it is assumed that the share of externalist students would be similar at other faculties, it would be an interesting stimulus for the system of counselling services at universities and also academics.

\section{Acknowledgement}

This study was created within the project of the Technology Agency of the Czech Republic called "Education in engineering and its optimisation for the needs of the labour market," registration number TJ 02000083, carried out at the Faculty of Education at the University of Ostrava between 2019 and 2021. 


\section{References}

Akca, F., Ulutas, E., \& Yabanci, C. (2018). Investigation of teachers' self-efficacy beliefs, locus of control and intercultural sensitivities from the perspective of individual differences. Journal of Education and Learning, 7(3), 219-232. https://doi.org/10.5539/jel.v7n3p219

Akkaya, R., \& Akyol, B. (2016). The relationship between teachers' locus of control and job satisfaction: A mixed method study. International Online Journal of Educational Sciences, 8(3), $71-82$.

American Psychological Association (n.d.). APA Dictionary of Psychology. Locus of control. https:// dictionary.apa.org/locus-of-control

Barot, T., Burgsteiner, H., \& Kolleritsch, W. (2020). Comparison of discrete autocorrelation functions with regards to statistical significance. In R. Silhavy (Ed.), Applied Informatics and Cybernetics in Intelligent Systems, Advances in Intelligent Systems and Computing (pp. 257-266). Springer. https://doi.org/10.1007/978-3-030-51974-2_24

Basak, R., \& Ghosh, A. (2011). School environment and locus of control in relation to job satisfaction among school teachers. A study from Indian perspective. Procedia-Social and Behavioral Sciences, 29, 1199-1208. https://doi.org/10.1016/j.sbspro.2011.11.354

Bean, J. P., \& Eaton, S. (2000). A psychological model of college student retention. In J. M. Braxton (Ed.), Reworking the departure puzzle: New theory and research on college student retention (pp. 73-89). University of Vanderbilt Press.

Bean, J. P., \& Metzner, B. S. (1985). A conceptual model of nontraditional undergraduate student attrition. Review of Educational Research, 55(4), 485-540. https://doi. org $/ 10.3102 / 00346543055004485$

Betoret, F. D. (2013). Teacher psychological needs, locus of control and engagement. Spanish Journal of Psychology, 16(e29), 1-13. https://doi.org/10.1017/sjp.2013.51

Bodill, K., \& Roberts, L. D. (2013). Implicit theories of intelligence and academic locus of control as predictors of studying behaviour. Learning and Individual Differences, 27, 163-166. https://doi.org/10.1016/j.lindif.2013.08.001

Brücknerová, K., \& Rabušicová, M. (2019). Netradiční vysokoškolští studenti: charakteristiky a potenciál odloženého studia. Studia Paedagogica, 24(1), 39-49. https://doi.org/10.5817/ SP2019-1-2

Cachia, M., Lynam, S., \& Stock, R. (2018). Academic success: Is it just about the grades? Higher Education Pedagogies, 3(1), 434-439. https://doi.org/10.1080/23752696.2018.1462096

Curtis, N. A., \& Trice, A. D. (2013). A revision of the academic locus of control scale for college students. Perceptual \& Motor Skills: Physical Development \& Measurement, 116(3), 817-829. https://doi.org/10.2466/08.03.PMS.116.3.817-829

Dolejš, M., Zemanová, V., \& Vavrysová, L. (2019). Vztah místa kontroly a rizikových aktivit u českých adolescentů. Diskuæe v psychologii, 1(1), 1-8. https://doi.org/10.5507/dvp.2019.002

Fazey, D. M. A., \& Fazey, J. A. (2001). The potential for autonomy in learning: Perceptions of competence, motivation and locus of control in first-year undergraduate students. Studies in Higher Education, 26(3), 345-361. https://doi.org/10.1080/03075070120076309

Fraser, W. J., \& Killen, R. (2003). Factors influencing academic success or failure of first-year and senior university students: Do education students and lecturers perceive things differently? South African Journal of Education, 23(4), 254-260.

Gauthier, T. D., \& Hawley, M. E. (2015). Statistical Methods. In B. L. Murphy, \& D. M. Robert (Eds.), Introduction to Environmental Forensics. (3rd edition, pp. 99-148). Elsevier. 
Gliszczyńska, X. (1990). Skala I-E w Pracy. Technika pomiaru poczucia kontroli w sytuacji pracy. Podręznik. Pracownia Testów Psychologicznych Polskiego Towarzystwa Psychologicznego.

Glossary of Educational Reform. (2013, October 25). Locus of control. https://www.edglossary. org/locus-of-control/

Hammer, Ø., Harper, D. A. T., \& Ryan, P. D. (2001). Past: Paleontological statistics software package for education and data analysis. Palaeontologia Electronica, 4(1), 1-9.

Kim, E., Newton, F. B., Downey, R. G., \& Benton, S. L. (2010). Personal factor impacting college student success: Constructing college learning effectiveness inventory (CLEI). College Student Journal, 44(1), 112-125.

Kiral, B. (2019). Exploring the relationship between teachers' locus of control with different variables. Educational Policy Analysis and Strategic Research, 14(2), 88-104. https://doi. org/10.29329/epasr.2019.201.5

Kitchenham, B., Madeyski, L., Budgen, D., Keung, J., Brereton, P., Charters, S., Gibbs, S., \& Pohthong A. (2017). Robust statistical methods for empirical software engineering. Empirical Software Engineering, 22(2), 579-630. https://doi.org/10.1007/s10664-016-9437-5

Lacková, L. (2014). Protective factors of university students. New Educational Review, 38(4), 273-286.

Levenson, H. (1973). Reliability and validity of the I, P, and C scales-a multidimensional view of locus of control. American Psychological Association Convention.

Mahajan, N., \& Kaur, J. (2012). Relation between locus of control of college teachers and their job satisfaction. International Journal of Applied Psychology, 2(5), 98-103. https://doi. org/10.5923/j.ijap.20120205.04

Mohamed, A. A., Mohammed, A. M., \& Ahmed, H. A-E. (2018). Relation between locus of control and academic achievement of nursing students at Damanhour university. IOSR Journal of Nursing and Health Science, 7(5) 1-13. https://doi.org/10.9790/1959-0705120113

Moses, L., Hall, C., Wuensch, K., De Urquidi, K., Kauffman, P., Swart, W., Duncan, S., \& Dixon, G. (2011). Are math readiness and personality predictive of first-year retention in engineering? Journal of Psychology, 145(3), 229-245. https://doi.org/10.1080/00223980.2 011.557749

Parys, K. (2018). Innowacyjność w pracy zawodowej i poczucie umiejscowienia kontroli działania pedagogów specjalnych. Rocそnik Komisji Nauk Pedagogicznych, 61, 126-142.

Poziemska, J. (2015, September 17). Poczucie umiejcowienia kontroli zdrazeń szkolnych a osiagniecia edukacyjne. XXI Krajowa Konferencja Diagnostyki Edukacyjnej-Zastosowania Diagnozy Edukacyjnej, Kraków, Poland.

Pšeno, M., \& Vavráková, E. (2015). Miesto kontroly a výchovný štýl rodičov. Psychológia a patopsychológia diet'at'a, 49(1-2), 40-49.

Procházka, J., Macanová, A., Mokrá, T., Nekulová, P., Vodička, A., Zezulka, R., Ježek, S., \& Vaculík, M. (2014). Vztah prokrastinace a locus of control v akademickém prostředí. Pedagogika, 64(4), 383-392.

Rose, J. S., \& Medway, F. J. (1981). Measurement of teachers' beliefs in their control over student outcome. Journal of Educational Research, 74(3), 185-189.

Rotter, A. (1966). Generalized expectancies for internal versus external control of reinforcements. Psychological Monographs: General and Applied, 80(1), 1-28. https://doi.org/10.1037/h0092976

Řehulková, J. (2007). Kognitivní styl, studijní styl a místo kontroly osobnosti. Československá psychologie, 51(3), 238-252. 
Strelnicki, A. M., Nordstokke, D. W., \& Saklofske, D. H. (2015). Who is the successful university student? An analysis of personal resources. Canadian Journal of Higher Education, 45(2), 214-228.

Suárez-Álvarez, J., Pedrosa, I., García-Cueto, E., \& Muñiz, J. (2016). Locus of control revisited: development of a new bi-dimensional measure. Anales de Psicologia, 32(2), 578-586. https:// doi.org/10.6018/analesps.32.2.200781

Švec, V., \& Koláčková, G. (2013). Teoretická východiska problematiky retence vysokoškolských studentů. Aula, 21(2), 56-69.

Toussi, M. T. M., \& Ghanizadeh, A. (2012). A study of EFL teachers' locus of control and self-regulation and the moderating role of self-efficacy. Theory and Practice in Language Studies, 2(11), 2363-2371. https://doi.org/10.4304/tpls.2.11.2363-2371

Trice, A. D. (1985). An academic locus of control scale for college students. Perceptual and Motor Skills, 61(3), 1043-1046. https://doi.org/10.2466/pms.1985.61.3f.1043

Vašutová, J. (2004). Profese učitele v českém vądélávacím kontextu. Paido.

Výrost, J. (2002). Od lokalizácie kontroly k vnímanej kontrole. Človek a spoločnost', 5(3), $39-43$.

Walczak, R. B., \& Wężowska, J. (2017). Gry fabularne jako sposób zwiększenia kontroli nad rzeczywistością. Poczucie umiejscowienia kontroli oraz emocjonalność graczy w porównaniu do młodzieży niegrającej. Homo Ludens, 1(10), 255-267.

Wolinsky, F. D., Vander Weg, M. W., Martin, R., Unverzagt, F. W., Willis, S. L., Marsiske, M., Rebok, G. W., Morris, J. N., Ball, K. K., \& Tennstedt, S. L. (2009). Does cognitive training improve internal locus of control among older adults? Journal of Gerontology: Social Sciences, 65(5), 591-598. https://doi.org/10.1093/geronb/gbp117

Zemanová, V., \& Dolejš, M. (2016). Škála mista kontroly Zemanová a Dolejš (SMKZD) [Unpublished manuscript]. Univerzita Palackého.

Zemanová, V., \& Dolejš, M. (2020). Vyhodnoceni Škály mista kontroly Zemanová Dolejš [Unpublished manuscript]. Univerzita Palackého.

\section{Corresponding authors}

Josef Malach

Department of Education and Adult Education,

Faculty of Education, University of Ostrava, Ostrava, Czech Republic

E-mail: josef.malach@osu.cz

Dana Vicherková

Department of Education and Adult Education, Faculty of Education, University of Ostrava, Ostrava, Czech Republic

E-mail: dana.vicherkova@osu.cz

Tomáš Barot

Department of Mathematics with Didactics

Faculty of Education, University of Ostrava, Ostrava, Czech Republic

E-mail: tomas.barot@osu.cz 
